\title{
Taxonomic Study of Coagulase-Positive Staphylococci: Bacteriolytic Activity Pattern Analysis
}

\author{
PIETRO E. VARALDO, ${ }^{1}$ GIUSEPPE SATTA, ${ }^{1}$ AND V. HÁJEK ${ }^{2}$ \\ Instituto di Microbiologia dell'Università di Genova, School of Medicine, Genova, Italy, ${ }^{1}$ and Department of \\ Microbiology, School of Medicine, Palacky University, Olomouc, Czechoslovakia ${ }^{2}$
}

\begin{abstract}
The taxonomic problem of coagulase-positive staphylococci of various origins is confronted in the present investigation by means of the bacteriolytic activity pattern analysis. A total of 103 strains isolated from various animal sources have been examined using the same assay system which in previous studies had been employed with staphylococci of human origin and had permitted their subdivision into six lyogroups. Two groups $(a$ and $b$ ) of coagulase-positive staphylococci have been recognized by this method. Group $a$ is shown to overlap exactly with the species Staphylococcus aureus, whereas group $b$ overlaps with the recently described species Staphylococcus intermedius. The results obtained are discussed, as related both to most recent data dealing with the taxonomy of coagulasepositive staphylococci and to previous findings on bacteriolytic activity patterns of staphylococci of human origin.
\end{abstract}

It has been shown recently that coagulasenegative as well as coagulase-positive staphylococci excrete an easily detectable bacteriolytic activity (7). Properties of such activities have been shown to differ in various strains. Based on the analysis of these differences by a particular assay system, staphylococci of human origin have been subdivided into six different groups (lyogroups) (11). The strains included in each lyogroup were found to share the major biochemical and metabolic properties. In particular, a significant overlapping of the staphylococcal lyogroups with the staphylococcal species identified according to Schleifer and Kloos $(5,8)$ has been demonstrated (10). This analysis also brought to light the important finding that strains producing different lytic enzymes generally belong to species with a different chemical cell wall composition. Based on this fact, it has been suggested that association between a specific cell wall chemical composition and a specific lytic enzyme can be the biochemical basis for events of primary importance in cell physiology, such as cell wall growth, cell septation, or cell division. Therefore, the analysis of the bacteriolytic activity pattern has been proposed as a new and valuable taxonomic method, suggesting extensive applications.

In the above-mentioned studies, coagulasepositive strains were all found to fall into one lyogroup, i.e., lyogroup 1 (10). This finding was consistent with the known physiological and taxonomic homogeneity of coagulase-positive staphylococci of human origin (1). Significant differences, on the contrary, have been reported to occur among coagulase-positive staphylococci of animal origin, depending on the animal source of the strains $(1,3,4)$. Therefore the problem is to establish whether such differences are either expression of host-dependent minor variations or are major differential characteristics among different species of coagulase-positive staphylococci. Coagulase-positive staphylococci have already been subdivided into six biotypes (A to $F$ ) (3). Recently, the traditional species Staphylococcus aureus, previously thought to coincide with coagulase-positive staphylococci, has been limited to biotypes $\mathrm{A}$ to $\mathrm{D}$, whereas biotypes $\mathrm{E}$ and $\mathrm{F}$ have been included into a new species named Staphylococcus intermedius (2).

In the present study, the bacteriolytic activity pattern analysis is used as a new way of approaching the taxonomic problem of coagulasepositive staphylococci of various origins. Two groups of coagulase-positive staphylococci have been recognized by this method; they are shown to overlap with $S$. aureus and $S$. intermedius, respectively.

\section{MATERIALS AND METHODS}

Bacterial strains. A total of 103 coagulase-positive staphylococci have been investigated. These strains have been obtained from various animal sources, using sheep or horse blood agar (blood agar base no. 2, Oxoid) and staphylococcus medium no. 110 (Oxoid) as isolating media. All strains had been analyzed previously for their physiological characteristics. The strains, their sources, classification, and the relative references are listed in Table 1.

Determination of the bacteriolytic activity pattern. The bacteriolytic activity pattern has been determined using the same assay system, composed of eight testing media, which in a previous study had 
TABLE 1. List of strains used

\begin{tabular}{|c|c|c|c|}
\hline Strain(s) & Source & $\begin{array}{c}\text { Taxonomic } \\
\text { position }\end{array}$ & Reference \\
\hline Cowan I & Human & $\begin{array}{l}\text { Staphylococcus aureus } \\
\text { (biotype A) }\end{array}$ & \\
\hline Wood 46 & Human & $\begin{array}{l}\text { S. aureus } \\
\text { (biotype A) }\end{array}$ & \\
\hline $\begin{array}{l}\text { AT12, BD16, BE8, } \\
\text { BZ20, O10 }\end{array}$ & Human & $\begin{array}{l}\text { S. aureus } \\
\text { (biotype A) }\end{array}$ & 10 \\
\hline B30, B61, B84 & Human & $\begin{array}{l}\text { S. aureus } \\
\text { (biotype A) }\end{array}$ & 4 \\
\hline $\begin{array}{l}\mathrm{S} 18, \mathrm{~S} 24, \mathrm{~S} 26, \mathrm{~S} 31, \mathrm{~S} 36 \\
\mathrm{~S} 42, \mathrm{~S} 45, \mathrm{~S} 50, \mathrm{~S} 70, \mathrm{~S} 83\end{array}$ & Poultry & $\begin{array}{l}\text { S. aureus } \\
\text { (biotype B) }\end{array}$ & 4 \\
\hline $\begin{array}{l}\text { V1, V12, V18, V } 22, \text { V } 26, \\
\text { V } 29, \text { V } 32, \text { V } 36, \text { V } 43, \text { V } 49\end{array}$ & Swine & $\begin{array}{l}\text { S. aureus } \\
\text { (biotype B) }\end{array}$ & 4 \\
\hline $\begin{array}{l}\text { M1, M4, M15, M21, M30, } \\
\text { M44, M57, M61, M76, M86 }\end{array}$ & Cow & $\begin{array}{l}\text { S. aureus } \\
\text { (biotype C) }\end{array}$ & 4 \\
\hline $\begin{array}{l}\mathrm{R} 7, \mathrm{R} 12, \mathrm{R} 27, \mathrm{R} 38, \mathrm{R} 40, \\
\mathrm{R} 53, \mathrm{R} 60, \mathrm{R} 74, \mathrm{R} 78, \mathrm{R} 82\end{array}$ & Sheep & $\begin{array}{l}\text { S. aureus } \\
\text { (biotype C) }\end{array}$ & 4 \\
\hline $\mathrm{Z1}, \mathrm{Z8}, \mathrm{Z} 20$ & Hare & $\begin{array}{l}\text { S. aureus } \\
\text { (biotype D) }\end{array}$ & 4 \\
\hline $\begin{array}{l}\mathrm{K} 2, \mathrm{~K} 6, \mathrm{~K} 7, \mathrm{~K} 15, \mathrm{~K} 18, \\
\mathrm{~K} 20, \mathrm{~K} 25, \mathrm{~K} 28, \mathrm{~K} 31, \mathrm{~K} 69\end{array}$ & Horse & $\begin{array}{l}\text { S. intermedius } \\
\text { (biotype E) }\end{array}$ & 2 \\
\hline $\begin{array}{l}\text { L1, L5, L18, L19, L27, } \\
\text { L28, L95, L99, L107, L108 }\end{array}$ & Mink & $\begin{array}{l}\text { S. intermedius } \\
\text { (biotype E) }\end{array}$ & 2 \\
\hline $\begin{array}{l}\text { P5, P11, P12, P16, P55, } \\
\text { P59, P67, P71, P75, P76 }\end{array}$ & Dog & $\begin{array}{l}\text { S. intermedius } \\
\text { (biotype E) }\end{array}$ & 2 \\
\hline $\begin{array}{l}\mathrm{H} 2, \mathrm{H} 4, \mathrm{H} 11, \mathrm{H} 13, \mathrm{H} 14, \\
\mathrm{H} 17, \mathrm{H} 20, \mathrm{H} 27, \mathrm{H} 30, \mathrm{H} 55\end{array}$ & Pigeon & $\begin{array}{l}\text { S. intermedius } \\
\text { (biotype F) }\end{array}$ & 2 \\
\hline $\begin{array}{l}\text { G1, G3, G5, G7, G8, G26, } \\
\text { G29, G34, G132, G141 }\end{array}$ & Fox & $\begin{array}{l}\text { S. intermedius } \\
\text { (biotype F) }\end{array}$ & 4 \\
\hline
\end{tabular}

allowed subdivision of human staphylococci into six lyogroups (11). Preparation of the bacteriolytic activity substrates, preparation and inoculation of the media, and evaluation of the bacteriolytic activity were carried out by the procedures described (11).

Bacteriolytic activity pattern analysis of the strains studied was performed without knowing strain origin and identification.

\section{RESULTS}

The bacteriolytic activity of the 103 strains studied was examined on the eight media of the assay system. The different patterns obtained and the number of strains exhibiting the same pattern are presented in Table 2. Based on pattern analysis and comparison, the strains tested could be subdivided into two different groups, designated $a$ and $b$. Within group $a$, two subgroups ( $a 1$ and $a 2$ ) were further recognized.

Group $a$. Fifty-three strains were included in group $a$ (41 in subgroup $a 1$ and 12 in subgroup a2). These strains showed a moderate to fairly large zone of transparency on TP2 medium with a rather indistinct outline. The zone of transparency on TP2P was absent or strongly decreased (subgroup a1) or identical (subgroup a2) as compared with that on TP2: this was the essential difference between the two subgroups. A very large zone of transparency was exhibited on TP1, generally with a sharp outline. A moderate activity was shown on T0; a large and well defined zone of transparency occurred on T1; no or very modest activity was found on T3. A well-defined zone of transparency appeared on B15TP1, whereas there was no activity on a61TP2.

Group $a$ included all the strains previously identified as $S$. aureus on the basis of other physiological characteristics (see Table 1) and none of the other strains tested. The bacteriolytic activity patterns of subgroup a1 strains could not be differentiated from those of lyogroup 1 strains (11) which, within isolates from humans, proved to perfectly overlap with $S$. aureus $(10)$. Therefore a precise overlap between group $a$ and the species $S$. aureus can be stated.

The strains and the lytic activity type pattern of group $a$ are shown in Table 3.

Group $b$. Fifty strains were included in group $b$. These strains produced a moderate zone of transparency on both TP2 and TP2P. Some, however, showed a slight activity decrease on the latter medium in comparison with the former. All strains showed a larger zone of transparency on TP1. Most strains exhibited a mod- 
TABLE 2. Bacteriolytic activity patterns of the 103 strains tested on the assay system media

\begin{tabular}{|c|c|c|c|c|c|c|c|c|c|c|c|}
\hline \multirow{2}{*}{$\begin{array}{c}\text { Pattern } \\
\text { no. }\end{array}$} & \multirow{2}{*}{$\begin{array}{l}\text { No. of } \\
\text { strains }\end{array}$} & \multicolumn{9}{|c|}{ Bacteriolytic activity on assay system medium: } & \multirow{2}{*}{$\begin{array}{l}\text { Group } \\
\text { and } \\
\text { no. of } \\
\text { strains }\end{array}$} \\
\hline & & TP1 & & TP2 & TP2P & T0 & $\mathrm{T} 1$ & T3 & B15TP1 & a61TP2 & \\
\hline 1 & 14 & +++ & $\bullet$ & + & - & \pm & ++ & - & + & - & \multirow{6}{*}{$a 1(41)$} \\
\hline 2 & 7 & +++ & & + & \pm & \pm & ++ & - & + & - & \\
\hline 3 & 9 & +++ & & + & - & + & ++ & - & + & - & \\
\hline 4 & 7 & +++ & & + & - & \pm & ++ & \pm & + & - & \\
\hline 5 & 1 & +++ & & + & - & + & ++ & \pm & + & - & \\
\hline 6 & 3 & +++ & & + & - & \pm & ++ & - & + & - & \\
\hline 7 & 7 & +++ & & + & + & + & ++ & \pm & + & - & \multirow{3}{*}{$a 2(12)$} \\
\hline 8 & 3 & +++ & & + & + & + & ++ & - & + & - & \\
\hline 9 & 2 & +++ & & + & + & \pm & ++ & - & + & - & \\
\hline 10 & 24 & ++ & & + & + & + & ++ & - & - & - & \multirow{5}{*}{$b \quad(50)$} \\
\hline 11 & 12 & ++ & & + & + & \pm & ++ & - & - & - & \\
\hline 12 & 3 & ++ & & + & + & + & ++ & \pm & - & - & \\
\hline 13 & 5 & ++ & & + & \pm & + & ++ & - & - & - & \\
\hline 14 & 6 & ++ & & + & \pm & + & ++ & \pm & - & - & \\
\hline
\end{tabular}

TABLE 3. Strains and bacteriolytic activity type patterns of the groups identified

\begin{tabular}{|c|c|c|c|c|c|c|c|c|c|c|}
\hline \multirow{2}{*}{ Group } & \multirow{2}{*}{ Strains } & \multirow{2}{*}{ Species } & \multicolumn{8}{|c|}{ Bacteriolytic activity type pattern on assay system medium: } \\
\hline & & & TP1 & TP2 & TP2P & T0 & $\mathbf{T 1}$ & T3 & B15TP1 & a61TP2 \\
\hline$a 1$ & $\begin{array}{l}\text { Cowan I } \\
\text { Wood 46 } \\
\text { AT12, BD16, BE8, BZ20, O10 } \\
\text { B30, B61, B84 } \\
\text { S18, S26 } \\
\text { V1, V12, V18, V22, V26, V29, } \\
\text { V32, V36, V43, V49 } \\
\text { M1, M4, M15, M21, M30, M44, } \\
\text { M57, M61, M76, M86 } \\
\text { R7, R12, R27, R38, R40 } \\
\text { R53, R60, R74, R78 }\end{array}$ & $\begin{array}{l}\text { Staphylococcus } \\
\text { aureus }\end{array}$ & +++ & + & - & \pm & ++ & - & + & - \\
\hline$a 2$ & $\begin{array}{l}\text { S24, S31, S36, S42, S45, } \\
\text { S50, S70, S83 } \\
\text { R82 } \\
\mathrm{Z1,} \mathrm{Z8,} \mathrm{Z20}\end{array}$ & S. aureus & +++ & + & + & + & ++ & \pm & + & - \\
\hline$b$ & $\begin{array}{c}\text { K2, K6, K7, K15, K18, K20, } \\
\text { K25, K28, K31, K69 } \\
\text { L1, L5, L18, L19, L27, L28 } \\
\text { L95, L99, L107, L108 } \\
\text { P5, P11, P12, P16, P55, P59, } \\
\text { P67, P71, P75, P76 } \\
\text { H2, H4, H11, H13, H14, H17, } \\
\text { H20, H27, H30, H55 } \\
\text { G1, G3, G5, G7, G8, G26, } \\
\text { G29, G34, G132, G141 }\end{array}$ & S. intermedius & ++ & + & + & + & ++ & - & - & - \\
\hline
\end{tabular}

erate activity on T0; a well defined zone of transparency was exhibited on $\mathrm{T} 1$; activity on T3 was either none or very modest. No zone of transparency appeared on B15TP1 and a61TP2. The bacteriolytic activity patterns of these strains were, on the whole, very similar to those of human strains included in lyogroup 2 (11).

Group $b$ included all the strains previously identified as $S$. intermedius on the basis of other physiological characteristics (see Table 1) and none of the other strains tested. Therefore a precise overlap between group $b$ and the species $S$. intermedius can be stated.

The strains and the bacteriolytic activity type pattern of group $b$ are shown in Table 3.

\section{DISCUSSION}

The present study, as compared with previous findings on bacteriolytic activity patterns of 
staphylococci of human origin $(10,11)$, shows that coagulase-positive staphylococci do not represent a homogeneous group of strains, when isolates from various animal sources other than humans are also considered. Two different type patterns of bacteriolytic activity have in fact been recognized, and two respective groups of coagulase-positive staphylococci ( $a$ and $b$ ) have been identified.

A perfect overlap between group $a$ and the species $S$. aureus has been demonstrated, as well as between group $b$ and the species $S$. intermedius. This fact significantly confirms the separation of $S$. intermedius from $S$. aureus (2), and also enhances the value of bacteriolytic activity pattern analysis in species separation.

The subdivision of group $a$ into the two subgroups $a 1$ and $a 2$-essentially based on the occurrence of a lytic activity decrease on TP2P with respect to TP2-probably has minor relevance to bacteriolytic activity. In fact TP2P is a phenolphthalein diphosphate-containing medium, and we have already observed inhibition of bacteriolytic enzymes owing to phosphatase activity in phenolphthalein diphosphate-containing media $(10,11)$. Therefore the difference between subgroups $a 1$ and $a 2$ seems more likely to be linked to quantitative and/or qualitative differences in phosphatase production (6; Grazi et al., manuscript in preparation).

The similarity in bacteriolytic activity pattern between group $b$ and lyogroup 2-the former corresponding to $S$. intermedius and the latter previously proven to overlap with Kloos and Schleifer's $S$. simulans (10)-suggests close physiological and taxonomic relations between these two groups of strains. Both have similarities to $S$. aureus and share several of its specific properties; both however, lack some of the most common characteristics of $S$. aureus and most other staphylococci: acetoin and pigment are not produced, and in peptone-containing media acid production from maltose is not detected $(2,5$, 10). Moreover, differences in the reported cell wall compositions of $S$. simulans (5) and $S$. intermedius (9) do not seem particularly sharp, when considering certain source-dependent variations in the serine content of $S$. intermedius peptidoglycan (9). Both group $b$ (or S. intermedius) in animals and lyogroup 2 (or S. simulans) in humans seem to occupy an intermediate position between $S$. aureus and $S$. epidermidis. Phylogenetic and ecological relations between these two groups of strains seem worthy of further investigation.

\section{ACKNOWLEDGMENT}

The valuable assistance of Carla Poggi is gratefully acknowledged.

\section{REPRINT REQUESTS}

Address reprint requests to: Dr. Pietro E. Varaldo, Instituto di Microbiologia dell'Università di Genova, Viale Benedetto $\mathrm{XV}, 10,16132$ Genova, Italy.

\section{LTERATURE CITED}

1. Baird-Parker, A. C. 1974. The basis for the present classification of staphylococci and micrococci. Ann. N.Y. Acad. Sci. 236:7-14.

2. Hájek, V. 1976. Staphylococcus intermedius, a new species isolated from animals. Int. J. Syst. Bacteriol. 26:401-408.

3. Hájek, V., and E. Maráálek. 1971. The differentiation of pathogenic staphylococci and a suggestion for their taxonomic classification. Zentralbl. Bakteriol. Parasitenkd. Infektionskr. Hyg. Abt. 1 Orig. Reihe A 217:176-182.

4. Hájek, V., and E. Maršálek. 1976. Evaluation of classificatory criteria for staphylococci. Zentralbl. Bakteriol. Parasitenkd. Infektionskr. Hyg. Abt. 1 Suppl. 5:11-21.

5. Kloos, W. E., and K. H. Schleifer. 1975. Isolation and characterization of staphylococci from human skin. II. Descriptions of four new species: Staphylococcus warneri, Staphylococcus capitis, Staphylococcus hominis, and Staphylococcus simulans. Int. J. Syst. Bacteriol. 25:62-79.

6. Oehring, H., and A. Bonow. 1974. Phosphatasebestimmungen an pyogenen Staphylokokken humaner und boviner Herkunft. Zentralbl. Bakteriol. Parasitenkd. Infektionskr. Hyg. Abt. 1 Orig. Reihe A 226:36-39.

7. Satta, G., P. E. Varaldo, G. Grazi, and R. Fontana. 1977. Bacteriolytic activity in staphylococci. Infect. Immun. 16:37-42.

8. Schleifer, K. H., and W. E. Kloos. 1975. Isolation and characterization of staphylococci from human skin. II. Amended descriptions of Staphylococcus epidermidis and Staphylococcus saprophyticus, and descriptions of three new species: Staphylococcus cohnii, Staphylococcus haemolyticus, and Staphylococcus xylosus. Int. J. Syst. Bacteriol. 25:50-61.

9. Schleifer, K. H., F. Schumacher-Perdreau, F. Götz, B. Popp, and V. Hájek. 1976. Chemical and biochemical studies for the differentiation of coagulase-positive staphylococci. Arch. Microbiol. 110:263-270.

10. Varaldo, P. E., and G. Satta. 1978. Grouping of staphylococci on the basis of their bacteriolytic activity patterns: a new approach to the taxonomy of the Micrococcaceae. II. Main characters of the 1,054 strains subdivided into "lyogroups." Int. J. Syst. Bacteriol. 28:148-153.

11. Varaldo, P. E., G. Satta, G. Grazi, and C. A. Romanzi. 1978. Grouping of staphylococci on the basis of their bacteriolytic activity patterns: a new approach to the taxonomy of the Micrococcaceae. I. Identification of six different "lyogroups." Int. J. Syst. Bacteriol. 28:141-147. 